\title{
PENGARUH PENERAPAN STRATEGI ACTIVE LEARNING TIPE QUESTION STUDENT HAVE TERHADAP KEAKTIFAN DAN PRESTASI BELAJAR MATEMATIKA PADA SISWA KELAS VII SMP SULTAN AGUNG SEYEGAN
}

\author{
Nugraheni Safitri ${ }^{1}$, Heru Sukoco ${ }^{2}$ \\ ${ }^{1,2}$ Program Studi Pendidikan Matematika, Fakultas Keguruan dan Ilmu Pendidikan, \\ Universitas Mercu BuanaYogyakarta \\ Email: nugraheni.safithree@gmail.com, heru-sukoco@mercubuana-yogya.ac.id
}

\begin{abstract}
Abstrak. Penelitian ini bertujuan untuk menjelaskan pengaruh penerapan strategi active learning tipe Question Student Have terhadap keaktifan dan prestasi belajar matematika siswa kelas VII SMP Sultan Agung Seyegan. Penelitian ini merupakan penelitian eksperimen dengan pretest-postest control group design. Populasi dalam penelitian ini adalah seluruh siswa kelas VII SMP Sultan Agung Seyegan pada semester kedua tahun pelajaran 2015/2016 yang terdiri atas dua kelas. Dua kelas tersebut digunakan sebagai sampel penelitian, yaitu kelas eksperimen dan kelas kontrol. Instrumen yang digunakan dalam penelitan ini adalah lembar observasi keaktifan belajar matematika siswa, pretest, dan posttest. Data penelitian dianalisis menggunakan uji t. Hasil penelitian ini menunjukkan bahwa penerapan strategi active learning tipe Question Student Have berpengaruh terhadap keaktifan dan prestasi belajar matematika siswa kelas VII SMP Sultan Agung Seyegan.
\end{abstract}

Kata kunci: strategi active learning tipe question student have, keaktifan siswa, prestasi belajar matematika

Abstract: This study aimed to clarify the effectiveness of the implementation of active learning strategy with question student have type toward students activeness and achievement in mathematics class VII SMP sultan Agung Seyegan. This study adopted a pretest-postest control group design in quasi eksperiment setting. The population in this study were all students of class VII SMP Sultan Agung Seyegan in the second semester of the academic year 2015/2016 consisted of two classes. Two classes were used as the research sample, namely experimental and control class. The instrument of the study was a activity of learning mathematics, pretest, and posttest. The data were analized using the one sample t test. The findings of the study show thatthe application of active learning of Question Student Have type affects on the mathematics students activeness and achievement of class VII at SMP Sultan Agung Seyegan.

Keywords: active learning strategy type of question student have, student activeness, mathematic students achievement

\section{PENDAHULUAN}

Matematika merupakan ilmu universal yang mendasari perkembangan teknologi modern, mempunyai peran penting dalam berbagai disiplin dan memajukan daya pikir manusia (Depdiknas, 2006:345). Sedangkan menurut Rezy Puspita Afriyeti (2014:1) mengatakan bahwa matematika merupakan salah satu disiplin ilmu yang mempunyai peranan penting dalam ilmu pengetahuan dan teknologi, serta berperan dalam menunjang ilmu-ilmu sosial dan budaya.Oleh karena itu, matematika mempunyai peran penting dalam berbagai 
disiplin ilmu seperti ilmu pengetahuan dan teknologi serta berperan dalam menunjang ilmuilmu sosial dan budaya.

Bagi seorang siswa, keberhasilan mempelajari matematika akan membuka pintu karir yang cemerlang sedangkan bagi suatu negara, matematika akan menyiapkan warganya untuk bersaing dan berkompetisi dibidang ekonomi dan teknologi (Hasratuddin, 133). Menurut Mohammad Nuh (2013:82) mengatakan bahwa hasil riset PISA (Program for International Student Assessment), studi yang memfokuskan pada literasi bacaan, matematika, dan IPA menunjukkan peringkat Indonesia baru bisa menduduki 10 besar terbawah dari 65 negara. Sedangkan menurut Hidayanti (2015) mengatakan bahwa pada Programme for International Student Assessment (PISA) matematika 2012 kemampuan siswa dalam menyelesaikan soal PISA masih rendah, anak Indonesia menduduki rangking 64 dari 65 negara. Jadi dapat disimpulkan bahwa prestasi belajar matematika anak di Indonesia masih rendah.

Lebih lanjut, berdasarkan data Departemen Pendidikan Nasional (Depdiknas,2015) tingkat Provinsi Yogyakarta juga menunjukkan bahwa hasil Ujian Nasional (UN) tahun 2014/2015 SMP Sultan Agung Seyegan menempati posisi rangking ke-378 dari 526 SMP/MTs/SMPT di Yogyakarta. Selain itu, nilai mata pelajaran matematika memperoleh nilai rata-rata lebih rendah dibandingkan dengan mata pelajaran yang lainnya.

Secara khusus, jika mencermati nilai rata-rata UTS matematika siswa semester 1 kelas VII SMP Sultan Agung Seyegan masih di bawah Kriteria Ketuntasan Minimal(KKM) yaitu 75. Hal ini dapat dilihat dari hasil UTS mata pelajaran matematika semester 1 tahun ajaran 2015/2016 kelas VII SMP Sultan Agung Seyegan sebagai berikut :

Tabel 1. Daftar Nilai Rata - Rata UTS Matematika Kelas VII SMP Sultan Agung Seyegan Semester 1 Tahun Ajaran 2015/2016

\begin{tabular}{ccc}
\hline Kelas & $\begin{array}{c}\text { Nilai Rata- } \\
\text { Rata }\end{array}$ & Keterangan \\
\hline VIIA & 71,7 & Dibawah KKM \\
\hline VIIB & 51,5 & Dibawah KKM \\
\hline
\end{tabular}

(Sumber : Laporan Nilai UTS Kelas VII Semester 1 Tahun Ajaran 2015/2016)

Selanjutnya, berdasarkan hasil observasi terhadap proses pembelajaran matematika di kelas VII SMP Sultan Agung Seyegan pada hari Sabtu tanggal 03 Oktober 2015, diperoleh keterangan bahwa siswa masih mengobrol dengan teman ketika pembelajaran matematika berlangsung. Siswa masih kurang aktif untuk bertanya kepada guru ketika ada kesulitan. Siswa juga kurang aktif dalam menjawab pertanyaan yang diberikan oleh guru. Sehingga guru harus menunjuk salah satu siswa untuk menjawab pertanyaan tersebut. Hal tersebut menunjukkan bahwa keaktifan belajar matematika siswa kelas VII SMP Sultan Agung Seyegan masih tergolong belum aktif.

Kenyataan di atas menunjukkan bahwa strategi pembelajaran yang digunakan guru saat mengajar belum memfasilitasi siswa untuk aktif di kelas. Pada saat guru menyampaikan materi dan memberikan contoh soal, siswa cenderung masih mengobrol dengan temannya. Ketika guru menanyakan kepada siswa tentang pemahaman siswa dengan materi yang disampaikan, siswa menjawab bahwa sudah paham. Namun ketika guru memberikan 
permasalahan yang baru, siswa cenderung masih bingung untuk menyelesaikan masalah tersebut.

Menurut Melvin L. Silberman (2013:91) strategi active learning tipe Question Student Have merupakan cara yang tidak membuat siswa takut untuk mempelajari apa yang mereka butuhkan dan harapkan. Cara ini menggunakan teknik mendapatkan partisipasi melalui tulisan daripada lisan atau percakapan (Hamruni, 2011:165). Menurut Rezy Puspita Afriyeti (2014:4) strategi ini merupakan pembelajaran dengan karakteristik adanya pertanyaan yang diajukan siswa. Dengan demikian, penerapan strategi active learning tipe Question Student Have dapat melibatkan semua siswa untuk berperan lebih aktif dan dapat mengetahui materi yang belum dipahami oleh siswa dalam pembelajaran matematika.

Melvin L. Silberman (2013:91-92) mengemukakan prosedur strategi active learning tipe Question Student Have sebagai berikut :

a. Berikan kartu indeks kosong kepada tiap siswa.

b. Perintahkan tiap siswa untuk menuliskan pertanyaan yang mereka miliki tentang materi pelajaran atau sifat dari pelajaran yang mereka ikuti (nama tidak perlu dicantumkan).

c. Bagikan kartu tersebut ke seluruh kelompok searah jarum jam. Ketika masing-masing kartu dibagikan kepada siswa berikutnya, dia harus membacanya dan memberi tanda centang pada kartu itu jika berisi pertanyaan yang merupakan persoalan yang dihadapi siswa yang membacanya.

d. Ketika semua kartu siswa kembali kepada pemiliknya, tiap siswa harus meninjau semua "pertanyaan" kelompok. Sampai di sini, kenali pertanyaan yang menerima banyak suara (tanda centang). Berikan jawaban kepada masing-masing pertanyaan ini dengan (a) memberikan jawaban yang langsung dan singkat; (b) menunda pertanyaan hingga waktu yang lebih tepat; atau (c) mengemukakan bahwa saat ini Anda belum mampu menjawab pertanyaan atau persoalan ini (janjikan jawaban secara pribadi, jika memungkinkan).

e. Perintahkan siswa untuk berbagi pertanyaan mereka secara sukarela, sekalipun pertanyaan mereka itu tidak mendapatkan suara (tanda centang) paling banyak.

f. Kumpulkan semua kartu. Kartu-kartu itu mungkin berisi pertanyaan yang dapat Anda jawab pada pelajaran atau pertemuan mendatang.

Dalam kegiatan belajar, subjek didik/siswa harus aktif berbuat (Sardiman, 2011:97).Menurut Melvin L. Silberman (2013:28) menggambarkan ketika kegiatan belajar bersifat aktif, siswa akan mengupayakan sesuatu. Dengan kata lain, menurut Sardiman (2011:97) dalam belajar sangat diperlukan adanya aktivitas.

Paul B. Diedrich (Sardiman, 2011:101) membuat suatu daftar yang berisi kegiatan siswa, antara lain dapat digolongkan sebagai berikut :

a. Visual activities, yang termasuk di dalamnya misalnya, membaca, memperhatikan gambar, memperhatikan demonstrasi, memperhatikan percobaan, memperhatikan pekerjaan orang lain.

b. Oral activities, seperti menyatakan, merumuskan, bertanya, memberi saran, mengeluarkan pendapat, mengadakan wawancara, diskusi, interupsi.

c. Listening activities, sebagai contoh mendengarkan : uraian, percakapan, diskusi, musik, pidato.

d. Writing activities, seperti misalnya menulis cerita, karangan, laporan, angket, menyalin. 
e. Drawing activities, misalnya : menggambar, membuat grafik, peta, diagram.

f. Motor activities, yang termasuk di dalamnya antara lain : melakukan percobaan, membuat konstruksi model, mereparasi, bermain, berkebun, berternak.

g. Mental activities, sebagai contoh misalnya : menanggapi, mengingat, memecahkan soal, menganalisis, melihat hubungan, mengambil keputusan.

h. Emotional activities, seperti misalnya, menaruh minat, merasa bosan, gembira, bersemangat, bergairah, berani, tenang, gugup.

Dalam Kamus Bahasa Indonesia dijelaskan bahwa prestasi belajar adalah penguasaan pengetahuan atau keterampilan yang dikembangkan melalui mata pelajaran, lazimnya ditunjukkan dengan nilai tes atau angka nilai yang diberikan oleh guru. Sedangkan menurut Ema Nurnisya Putri (2015) prestasi belajar siswa adalah hasil yang didapat oleh siswa setelah melalui kegiatan penilaian dan /atau pengukuran prestasi belajar berupa huruf atau kata atau simbol.

Menurut Muhibin Syah (2010:148-149) indikator prestasi belajar dari ranah cipta kognitif siswa adalah siswa dapat :

1. membandingkan (pengamatan)

2. menyebutkan dan menunjukkan

kembali (ingatan)

3. menjelaskan dan mendefinisikan dengan lisan sendiri (pemahaman)

4. memberikan contoh (penerapan)

5. menguraikan (analisis)

Keempat indikator di atas dievaluasi dengan cara tes tertulis.

Berdasarkan uraian di atas, prestasi belajar matematika adalah suatu hasil yang telah dicapai oleh siswa tentang penguasaan pengetahuan terhadap mata pelajaran matematika yang ditunjukkan dengan nilai tes atau angka nilai yang diberikan oleh guru.

\section{METODE PENELITIAN}

\section{Jenis Penelitian}

Jenis penelitian ini adalah penelitian eksperimen semu (quasi experiment). Dalam penelitian ini, peneliti memilih jenis penelitian eksperimen semu (quasi experiment) karena peneliti tidak mengacak subyek dan membentuk kelas baru melainkan menggunakan subyek yang sudah ada dalam kelas tersebut.

\section{Desain Penelitian}

Desain dalam penelitian ini adalah Pretest-Postest Control Group Design. Dalam penelitian ini, peneliti memberikan pretest sebelum perlakuan dan posttest setelah perlakuan pada kedua kelas yaitu kelas eksperimen dan kelas kontrol. Tabel desain penelitian dinyatakan sebagai berikut (Saifuddin Azwar, 2013:118) :

Tabel 2. Desain Eksperimen Pretest Postest Control Group Design

\begin{tabular}{lccc}
\hline \multicolumn{1}{c}{ Kelas } & Pre-test & Perlakuan & Posttest \\
\hline Eksperimen & $\mathrm{O}_{1}$ & $\mathrm{X}$ & $\mathrm{O}_{3}$ \\
\hline Kontrol & $\mathrm{O}_{2}$ & - & $\mathrm{O}_{4}$ \\
\hline
\end{tabular}

Keterangan:

$\mathrm{X}=$ pembelajaran matematika dengan strategi active learning tipe Question Student Have

- $\quad=$ pembelajaran matematika dengan strategi pembelajaran konvensional

$\mathrm{O}_{1}=$ pretest pada kelas eksperimen 


$$
\begin{aligned}
& \mathrm{O}_{2}=\text { pretest pada kelas kontrol } \\
& \mathrm{O}_{3}=\text { posttest pada kelas eksperimen } \\
& \mathrm{O}_{4}=\text { posttest } \text { pada kelas kontrol }
\end{aligned}
$$

\section{Tempat dan Waktu Penelitian}

Penelitian ini dilaksanakan di kelas VII SMP Sultan Agung Seyegan Tahun Pelajaran 2015/2016 yang beralamatkan di Jln. Kebonagung km. 17, Susukan, Sumberarum, Seyegan, Sleman, Yogyakarta. Waktu penelitian adalah waktu yang digunakan selama penelitian berlangsung. Dalam penelitian ini, waktu penelitian dilakukan pada semester 2 Tahun Pelajaran 2015/2016.

\section{Populasi dan Sampel Penelitian}

Populasi dalam penelitian ini adalah seluruh siswa kelas VII SMP Sultan Agung Seyegan tahun pelajaran 2015/2016 yang terdiri atas dua kelas yaitu kelas VIIA berjumlah 29 siswa dan VIIB berjumlah 28 siswa. Jadi jumlah siswa kelas VII adalah 57 siswa. Pada penelitian ini, diambil siswa dari dua kelas sebagai sampel penelitian yaitu siswa kelas VIIB sebagai kelas eksperimen dengan menggunakan strategi active learning tipe Question Student Have. Sedangkan siswa kelas VIIA sebagai kelas kontrol dengan menggunakan strategi pembelajaran konvensional.

\section{Teknik Pengumpulan Data}

Teknik pengumpulan data dalam penelitian ini meliputi tahapan sebagai berikut :

a. Menyusun instrumen penelitian

b. Meminta guru dan dosen untuk memvalidasi instrumen penelitian

c. Uji coba instrumen penelitian

d. Memberikan pretest kepada sampel penelitian

e. Melakukan penelitian

f. Memberikan posttest kepada sampel penelitian

\section{Teknik Analisis Data}

Untuk mendeskripsikan lembar observasi keaktifan siswa dilakukan dengan cara melihat kecenderungan terjadinya aktivitas pada setiap indikator yang diamati yaitu :

1) Masing-masing butir pernyataan pada lembar observasi keaktifan dikelompokkan sesuai dengan aspek-aspek yang diamati.

2) Berdasarkan pedoman penskoran yang telah dibuat dalam lembar observasi keaktifan siswa, kemudian dihitung jumlah skor tiap-tiap butir pernyataan dan disesuaikan dengan kriteria pemberian skor keaktifan.

Tabel 3. Kriteria Pemberian Skor Keaktifan

\begin{tabular}{cccccc}
\hline Sifat & \multicolumn{5}{c}{ Kriteria Pemberian Skor Keaktifan } \\
\cline { 2 - 6 } Pernyataan & $\begin{array}{c}\text { Sangat } \\
\text { tinggi }\end{array}$ & Tinggi & Sedang & Rendah & $\begin{array}{c}\text { Sangat } \\
\text { rendah }\end{array}$ \\
\hline Positif & 5 & 4 & 3 & 2 & 1 \\
\hline Negatif & 1 & 2 & 3 & 4 & 5 \\
\hline
\end{tabular}


Keterangan :

a) Skor 1 jika banyaknya siswa yang melakukan aktivitas terhitung 0 sampai 6 .

b) Skor 2 jika banyaknya siswa yang melakukan aktivitas terhitung 7 sampai 12 .

c) Skor 3 jika banyaknya siswa yang melakukan aktivitas terhitung 13 sampai 18 .

d) Skor 4 jika banyaknya siswa yang melakukan aktivitas terhitung 19 sampai 24 .

e) Skor 5 jika banyaknya siswa yang melakukan aktivitas terhitung 25 sampai 29.

3) Menghitung persentase masing-masing indikator dan persentase seluruh indikator dari lembar observasi keaktifan siswa pada kelas eksperimen dan kelas kontrol. Rumus yang digunakan untuk menghitung persentase keaktifan siswa yaitu sebagai berikut:

Keterangan :

$$
\text { Persentase keaktifan siswa }=\frac{k}{l} \times 100 \%
$$

$\mathrm{k} \quad=$ skor hasil observasi

$1 \quad=$ skor maksimal

Skor hasil observasi diperoleh berdasarkan jumlah indikator - indikator aktivitas siswa yang telah dilaksanakan.Skor maksimal adalah banyaknya kriteria penilaian dikalikan jumlah indikator aktivitas yang dilakukan oleh siswa pada lembar observasi.

4) Untuk mendeskripsikan data hasil lembar observasi keaktifan siswadari kelas eksperimen dan kontrol digunakan lima kategori keaktifan siswa. Adapun kategori keaktifan siswa adalah sebagai berikut :

Tabel 4. Kategori Keaktifan Siswa (Vita Nurvatimah, 2013)

\begin{tabular}{cl}
\hline $\begin{array}{c}\text { Persentase } \\
\text { keaktifan }(\%)\end{array}$ & \multicolumn{1}{c}{ Kategori } \\
\hline$\geq 80$ & Sangat tinggi \\
\hline $60-79$ & Tinggi \\
\hline $40-59$ & Sedang \\
\hline $20-39$ & Rendah \\
\hline$<20$ & Sangat rendah \\
\hline
\end{tabular}

Untuk mendeskripsikan data pretest dan posttest dari kelompok eksperimen dan kontrol digunakan teknik statistik yang meliputi rata-rata, ragam (variansi), standar deviasi, skor maksimum dan skor minimum, persentase ketuntasan, dan peningkatan persentase ketuntasan.

Selanjutnya, data penelitian dianalisis menggunakan uji t untuk mengetahui pengaruh penerapan strategi active learning tipe Question Student Have terhadap keaktifan dan prestasi belajar matematika siswa kelas VII SMP Sultan Agung Seyegan. Kriteria keputusan diambil berdasarkan analisis nilai $t_{\text {hitung }}$ yang dihasilkan dibandingkan dengan $t_{\text {tabel }}$ pada taraf signifikansi $5 \%$. Sebelum dilakukan uji t terlebih dahulu harus dipenuhi asumsi kenormalan dengan menggunakan uji kolmogorov-smirnov. 


\section{HASIL DAN PEMBAHASAN}

\section{Hasil Penelitian}

Data yang diperoleh dalam penelitian ini adalah skor keaktifan dan prestasi belajar matematika siswa. Berikut disajikan deskripsi data hasil lembar observasi keaktifan belajar matematika siswa :

Tabel 5. Deskripsi Hasil Lembar Observasi Keaktifan Siswa

\begin{tabular}{lcccc}
\hline \multirow{2}{*}{ Indikator } & \multicolumn{2}{c}{ Kelas eksperimen } & \multicolumn{2}{c}{ Kelas kontrol } \\
\cline { 2 - 5 } & $\begin{array}{c}\text { Sebelum } \\
\text { perlakuan }\end{array}$ & $\begin{array}{c}\text { Setelah } \\
\text { perlakuan }\end{array}$ & $\begin{array}{c}\text { Sebelum } \\
\text { perlakuan }\end{array}$ & $\begin{array}{c}\text { Setelah } \\
\text { perlakuan }\end{array}$ \\
\hline Keaktifan (\%) & 41,38 & 79,58 & 45,98 & 66,39 \\
\hline $\begin{array}{l}\text { Kategori } \\
\text { keaktifan }\end{array}$ & Sedang & Tinggi & Sedang & Tinggi \\
\hline
\end{tabular}

Berdasarkan hasil analisis statistik deskriptif seperti yang disajikan pada Tabel 5, hasil pengukuran menunjukkan bahwa rata - rata hasil pengukuran keaktifan siswa pada kelas eksperimen $79,58 \%$ dengan kategori keaktifan siswa tinggi. Sedangkan rata - rata hasil pengukuran keaktifan siswa pada kelas kontrol 66,39\% dengan kategori keaktifan siswa tinggi.

Selanjutnya, berikut disajikan pula deskripsi data hasil prestasi belajar matematika siswa sebelum dan setelah perlakuan :

Tabel 6. Deskripsi Hasil Prestasi Belajar Matematika Siswa

\begin{tabular}{lcccc}
\hline \multirow{2}{*}{ Deskripsi } & \multicolumn{2}{c}{ Kelas Eksperimen } & \multicolumn{2}{c}{ Kelas Kontrol } \\
\cline { 2 - 5 } & $\begin{array}{c}\text { Sebelum } \\
\text { perlakuan }\end{array}$ & $\begin{array}{c}\text { Setelah } \\
\text { perlakuan }\end{array}$ & $\begin{array}{c}\text { Sebelum } \\
\text { perlakuan }\end{array}$ & $\begin{array}{c}\text { Setelah } \\
\text { perlakuan }\end{array}$ \\
\hline Rata - rata & 21,71 & 83,75 & 27,28 & 77,72 \\
\hline Standar deviasi & 6,531 & 7,604 & 6,502 & 5,861 \\
\hline Variansi & 42,656 & 57,824 & 42,278 & 34,350 \\
\hline Skor minimum & 10 & 70 & 18 & 70 \\
\hline Skor maksimum & 33 & 95 & 42 & 92 \\
\hline Persentase ketuntasan & $0 \%$ & $85,71 \%$ & $0 \%$ & $75,86 \%$ \\
\hline $\begin{array}{l}\text { Peningkatan persentase } \\
\text { ketuntasan }\end{array}$ & \multicolumn{2}{c}{$85,71 \%$} & \multicolumn{2}{c}{$75,86 \%$} \\
\hline
\end{tabular}

Data penelitian ini dianalisisuntuk mengetahui pengaruh penerapan strategi active learning tipe Question Student Have terhadap keaktifan dan prestasi belajar matematika siswa kelas VII SMP Sultan Agung Seyegan. Analisis yang digunakan yaitu uji t. Sebelum dilakukan uji t terlebih dahulu harus dipenuhi asumsi normalitas data menggunakan uji Kolmogorov-Smirnov.

Berikut disajikan hasil uji normalitas data keaktifan dan prestasi belajar matematika siswa sebelum perlakuan : 
Tabel 7. Deskripsi Hasil Uji Normalitas Data Keaktifan dan Prestasi Belajar Matematika Siswa Sebelum Perlakuan Pada KelasEksperimen dan Kelas Kontrol

\begin{tabular}{llcc}
\hline \multirow{2}{*}{ Kelas } & \multicolumn{1}{c}{ Variabel } & $\begin{array}{c}\text { Nilai } \\
\text { signifikansi }\end{array}$ & \multicolumn{1}{c}{ Keterangan } \\
\hline \multirow{2}{*}{ Kelas eksperimen } & Keaktifan siswa & 0,200 & Distribusi normal \\
\cline { 2 - 4 } & Prestasi belajar pretest $)$ & 0,063 & Distribusi normal \\
\hline \multirow{2}{*}{ Kelas kontrol } & Keaktifan siswa & 0,200 & Distribusi normal \\
\cline { 2 - 4 } & Prestasi belajar pretest $)$ & 0,180 & Distribusi normal \\
\hline
\end{tabular}

Selain itu, berikut juga disajikan hasil uji normalitas data keaktifan dan prestasi belajar matematika siswa setelah perlakuan:

\section{Tabel 8. Deskripsi Hasil Uji Normalitas Data Keaktifan dan Prestasi Belajar Matematika Siswa Setelah Perlakuan Pada Kelas Eksperimen dan KelasKontrol}

\begin{tabular}{llcc}
\hline \multicolumn{1}{c}{ Kelas } & \multicolumn{1}{c}{ Variabel } & Nilai & Keterangan \\
\hline \multirow{2}{*}{ Kelas eksperimen } & Keaktifan siswa & 0,200 & Distribusi normal \\
\cline { 2 - 4 } & Prestasi belajar (posttest) & 0,193 & Distribusi normal \\
\hline \multirow{2}{*}{ Kelas kontrol } & Keaktifan siswa & 0,088 & Distribusi normal \\
\cline { 2 - 4 } & Prestasi belajar (posttest) & 0,186 & Distribusi normal \\
\hline
\end{tabular}

Berdasarkan Tabel 6 dan Tabel 8 diketahui bahwa nilai signifikansi KolmogorovSmirnov secara keseluruhan adalah lebih dari taraf signifikansi 0,05 sehingga $\mathrm{H}_{0}$ diterima. Artinya, semua data keaktifan dan prestasi belajar matematika siswa baik sebelum perlakuan maupun setelah perlakuan berasal dari populasi yang berdistribusi normal.

Uji t yang digunakan dalam penelitian ini yaitu One Sample T-Test. Hasil uji One Sample T-Test untuk keaktifan dan prestasi belajar matematika siswa menunjukkan nilai sig. 2-tailed < taraf signifikansi $(0,05)$ sehingga $\mathrm{H}_{0}$ ditolak. Hal ini berarti bahwa rata - rata keaktifan belajar matematika siswa yang menerapkan strategi active learning tipe Question Student Have mencapai batas minimal kategori keaktifan siswa tinggi dan prestasi belajar matematika siswa yang menerapkan strategi active learning tipe Question Student Have mencapai KKM.

Selain itu, juga digunakan uji t Paired Sample T-Test. Hasil uji Paired Sample T-Test untuk keaktifan dan prestasi belajar matematika siswa yang menerapkan strategi active learning tipe Question Student Have menunjukkan nilai sig. 2-tailed < taraf signifikansi $(0,05)$ sehingga $\mathrm{H}_{0}$ ditolak. Hal ini berarti bahwa ada peningkatan rata - rata persentase keaktifan belajar matematika siswa dan peningkatan rata - rata nilai prestasi belajar matematika siswa antara sebelum dan setelah adanya perlakuan.

Hasil uji Paired Sample T-Test untuk keaktifan dan prestasi belajar matematika siswa yang menerapkan strategi pembelajaran konvensional menunjukkan nilai sig. 2-tailed < taraf signifikansi $(0,05)$ sehingga $\mathrm{H}_{0}$ ditolak. Hal ini berarti bahwa ada peningkatan rata - rata persentase keaktifan belajar matematika siswa dan peningkatanrata - rata nilai prestasi belajar matematika siswa antara sebelum dan setelah adanya perlakuan. 
Selanjutnya, uji t yang digunakan dalam penelitian ini yaitu Independent Sample T-Test. Berdasarkan hasil perhitungan dengan software SPSS statistics 20 diperoleh nilai signifikansi Levene's Test $0,436>0,05$. Hal ini berarti bahwa varians dari kesdua kelas sama. Nilai t yang diperoleh yaitu 4,387dengan signifikansi $0,001<0,05$ sehingga $\mathrm{H}_{0}$ ditolak. Hal ini berarti bahwa rata - rata persentase keaktifan belajar matematika siswapada kelas eksperimen lebih baik dibandingkan dengan kelas kontrol.

Berdasarkan hasil perhitungan dengan software SPSS statistics 20 diperoleh nilai signifikansi Levene's Test 0,057 > 0,05. Hal ini berarti bahwa varians dari kedua kelas sama. Nilai t yang diperoleh yaitu 3,358 dengan signifikansi $0,001<0,05$ sehingga $\mathrm{H}_{0}$ ditolak. Hal ini berarti bahwa rata - rata nilai prestasi belajar matematika siswa pada kelas eksperimen lebih baik dibandingkan dengan kelas kontrol.

Jadi, penerapan strategi active learning tipe Question Student Have berpengaruh terhadap keaktifan dan prestasi belajar matematika siswa kelas VII SMPSultan Agung Seyegan.

\section{Pembahasan}

Berdasarkan hasil analisis data yang dilakukan pada Tabel 5 dan Tabel 7 dapat diketahui bahwa hasil persentase keaktifan dan nilai prestasi belajar matematika siswa yang belajar menggunakan strategi active learning tipe Question Student Have lebih baik daripada siswa yang belajar menggunakan strategi pembelajaran konvensional. Hal ini sesuai dengan penelitian yang dilakukan oleh Rinaldi Kurnia E. \& Edy Sulistyo (2015:765) yang menunjukkan bahwa rata-rata hasil belajar siswa yang mendapatkan pembelajaran dengan strategi pembelajaran aktif tipe Question Student Have lebih baik daripada rata-rata hasil belajar siswa yang mendapatkan pembelajaran dengan strategi konvensional.

Berdasarkan hasil analisis One Sample T-Test dengan menggunakan bantuan software SPSS Statistics 20 diperoleh hasil bahwa rata - rata keaktifan belajar matematika siswayang menerapkan strategi active learning tipe Question Student Have mencapai batas minimal kategori keaktifan siswa tinggi. Selain itu, diperoleh juga hasil bahwa rata - rata prestasi belajar matematika siswa yang menerapkan strategi active learning tipe Question Student Have mencapai KKM. Dengan demikian dapat disimpulkan bahwa penerapan strategi active learning tipe Question Student Have efektif ditinjau dari keaktifan dan prestasi belajar matematika siswa.

Lebih lanjut, berdasarkan hasil analisis Paired Sample T-Test yang telah dilakukan menunjukkan bahwa ada peningkatan dalam aspek keaktifan dan prestasi belajar matematika siswa dari sebelum adanya perlakuan sampai setelah adanya perlakuan strategi active learning tipe Question Student Have begitu pula pada penerapan strategi pembelajaran konvensional. Akan tetapi, peningkatan aspek keaktifan dan prestasi belajar matematika siswa pada kelas yang menggunakan strategi active learning tipe Question Student Have lebih tinggi daripada kelas yang menggunakan strategi pembelajaran konvensional.Hal tersebut sesuai dengan hasil penelitian yang dilakukan oleh Elita De Oviraet al (2015:325) yang menunjukkan bahwa penggunaan strategi pembelajaran aktif tipe Questions Students Have dapat meningkatkan aktivitas belajar dan hasil belajar siswa lebih tinggi secara signifikan daripada strategi pembelajaran konvensioanal. 
Selanjutnya, berdasarkan hasil analisis Independent Sample T-Test dengan menggunakan bantuan software SPSS Statistics 20 diperoleh hasil bahwa keaktifan dan prestasi belajar matematika siswa dengan menggunakan strategi active learning tipe Question Student Have dan strategi pembelajaran konvensional berbeda secara signifikan. Dengan demikian dapat disimpulkan bahwa penerapan strategi active learning tipe Question Student Have lebih baik dibandingkan dengan strategi pembelajaran konvensional ditinjau dari keaktifan dan prestasi belajar matematika siswa.

\section{KESIMPULAN}

Berdasarkan hasil penelitian dan pembahasan yang telah dikemukakan pada bab sebelumnya, maka dapat disimpulkan sebagai berikut :

1. Penerapan strategi active learning tipe Question Student Have berpengaruh terhadap keaktifan belajar matematika siswa kelas VII SMP Sultan Agung Seyegan.

2. Penerapan strategi active learning tipe Question Student Have berpengaruh terhadap prestasi belajar matematika siswa kelas VII SMP Sultan Agung Seyegan.

\section{DAFTAR PUSTAKA}

Departemen Pendidikan Nasional (Depdiknas). 2006. Peraturan Menteri Nomor 22 Tahun 2006 tentang standar isi untuk satuan pendidikan dasar dan menengah.

Departemen Pendidikan Nasional (Depdiknas) tingkat Provinsi Yogyakarta. Daftar sekolah SMP/MTs/SMPT berdasarkan jumlah nilai Ujian Nasional SMP/MTs/SMPT tahun pelajaran 2014/2015.www.pendidikan-diy.go.id diakses pada tanggal 2 Desember 2015.

Elita De Ovira, Irma Mon, dan Isniyetti. 2015. Penerapan pembelajaran aktif tipe Question Student Have (QSH) pada materi tata nama senyawa dan persamaan reaksi kimia di kelas X SMAN 7 Padang, Prosiding Simposium Nasional Inovasi dan Pembelajaran Sains2015 (SNIPS 2015), Bandung.

Ema Nurnisya Putri. 2015. Pengaruh kelelahan dan motivasi terhadap prestasi belajar matematika siswa Sekolah Menengah Atas Negeri Olahraga Sriwijaya Provinsi Sumatera Selatan, Prosiding Seminar Nasional Pendidikan Matematika (SNAPTIKA), Palembang.

Hamruni. 2011. Strategi pembelajaran. Yogyakarta: Insan Madani.

Hasratuddin. Membangun karakter melalui pembelajaran matematika. Jurnal Volume 6 Nomor 2.

Hidayanti. 2015. Pengembangan soal open ended pada pembelajaran matematika untuk mengidentifikasi kemampuan berfikir kreatif siswa, Prosiding Seminar Nasional Pendidikan Matematika (SNAPTIKA), Palembang.

Melvin L. Silberman. 2013. Active learning : 101 cara belajar siswa aktif. Bandung: Penerbit Nusamedia \& Nuansa Cendekia.

Mohammad Nuh. 2013. MATEMATIKA kelas X. Jakarta: Polikteknik Negeri Media Kreatif.

Muhibbin Syah. 2009. Psikologi pendidikan dengan pendekatan baru. Bandung: PT Remaja Rosdakarya.

Rezy Puspita Afriyeti. 2014. Penerapan strategi pembelajaran aktif tipe Question Student Have (QSH) melalui pendekatan kontekstual pada pembelajaran matematika di kelas VIII SMPNegeri 5 Padang Panjang.Jurnal. Padang Panjang: Program Studi Pendidikan 
Matematika Jurusan Pendidikan Matematika dan IPA Fakultas Keguruan dan Ilmu Pendidikan Universitas Muhammadiyah Sumatera Barat.

Rinaldi Kurnia E. \& Edy Sulistyo. 2015. Pengaruh strategi belajar Question Student Have (pertanyaan dari siswa) terhadap hasil belajar siswa pada standar kompetensi menjelaskan dasar - dasar sinyal video di SMK Raden Patah Mojokerto. Jurnal Volume 04 Nomor 03. Surabaya: Pendidikan Teknik Elektro Fakultas Teknik Universitas Negeri Surabaya.

Saifuddin Azwar. 2013. Penyusun skala psikologi edisi 2. Yogyakarta: Pustaka Pelajar.

Sardiman. 2011. Interaksi \& motivasi belajar mengajar. Jakarta: PT Rajagrafindo Persada.

Vita Nurvatimah. 2013. Pendekatan Realistic Mathematics Education dan PAKEM untuk meningkatkan aktivitas dan hasil belajar matematika siswa kelas VB SD Negeri 8 Metro Timur tahun pelajaran 2012/2013. Jurnal. Lampung: FKIP Universitas Lampung 